\title{
Translating Sexual Awakening in Marie Darrieussecq's Clèves
}

\author{
Pauline Henry-Tierney
}

FollOWING THE PUBLICATION of the English translation of her fourteenth

novel, Clèves (2011), ${ }^{1}$ Marie Darrieussecq discussed her writing project in an interview for BBC Radio Four, stating that she "wanted to write an organic book, with feelings from the body disregarding morals, disregarding stereotypes, magazines, all this, I just wanted to remember, from my own body, my young body." ${ }^{2}$ Indeed, Clèves $^{3}$ is unique in the way in which it offers an intimate insight into female adolescent sexuality, via its protagonist, Solange, whom we encounter at various junctures in her journey of sexual awakening. From the palpable experience of her first menstruation, to her first exciting yet discomforting sexual experiences with a boy named Arnaud, and finally her more pleasurable, yet morally questionable, sexual liaison with her much older former childminder, M. Bihotz, Darrieussecq writes graphically and uncompromisingly about the lived realities of female adolescence.

Yet what exactly is an "organic book," as Darrieussecq describes the text, and what processes are involved in writing it? In her article, "Theorizing Feminist

Discourse/Translation," feminist theorist and translator Barbara Godard asserts that "everywhere women are writing their way into subjective agency, dis/placing themselves." For Godard, the act of writing is an act of empowerment, writing the "inédit," namely the unwritten experiences of women, affirms subjecthood, placing women at the center of their own narratives of lived experience, displacing them from fictional and 'factual' 
representations of women configured through phallocentric discourses. She sees this act of writing as a process of translation: translation first "as notation of 'gestural' and other codes from what has been hitherto "unheard of"” and second, as "displacement of the dominant discourse" (Godard 46). My intention here is to read Darrieussecq's "organic writing" as a form of translation, tracing how she translates corporeal experience into language in order to express the "inédit" of female adolescent sexuality and construct an autonomous desiring self. Thereafter, looking to Penny Hueston's English translation, All the Way (2013), I will explore what happens when this newly constructed 'self' is displaced by another self, namely, a translator, when it journeys into a different cultural and linguistic context. In both cases I will look at translation through the prism of an embodied, situated praxis.

\section{Organic writing and orality}

Darrieussecq's desire to write an “organic book” echoes Marguerite Duras's words in her conceptualization of women's writing:

I think "feminine literature" is an organic, translated writing ... translated from blackness, from darkness. Women have been in darkness for centuries. They don't know themselves. Or only poorly. When women write they translate this darkness. ${ }^{5}$

The darkness, which Duras describes, relates to the prediscursive machinations of women's lived experiences, unknown in the sense that they exist outside of codified discourses established according to patriarchal logic. This writing is organic in the literal sense, as being related to or derived from living matter. As with Godard, Duras sees the bringing into language of these modes of being as a form of translation. In writing an organic book, then, 
Darrieussecq's work is first and foremost as a translator. Yet how does she translate? I would argue that hers is a translational praxis both with and of the body.

First, one of the ways in which the body is implicated within this translational praxis is via orality. In the $\mathrm{BBC}$ interview, Darrieussecq said that she returned to her teenage audio diaries to find the "raw material" for the book. It is interesting that she should choose recourse to audio texts instead of written diaries, which shows a desire to connect with her teenage self in a more physical way. In his article on vocality, "Le grain de la voix," Roland Barthes talks about how the body is embedded in orality. Taking the singing subject as an example, Barthes shows how the body marks its presence in the voice via gestures such as changes in breathing and movements such as the contraction and expansion of the diaphragm muscles. He calls these corporeal traces “le grain”: “Le grain,' ce serait cela: la matérialité du corps parlant sa langue maternelle: peut-être la lettre; presque sûrement la signifiance."6 Vocality, for Barthes, signals the way in which the voice (and thus the body) can exist independently of language. In this sense, vocality stands as a marker of signifiance, whereby meaning is created at the level of the body, instead of meaning being ascribed to the body. Vocality, then, according to Barthes, presents the possibility to "échapper à la tyrannie de la signification"7 and, more specifically, in the case of a female body, as Eugenia Loffredo underlines, to escape "the tyranny of the meanings established by patriarchal society." 8 Through the act of listening, which in itself is an unmediated erotic experience according to Barthes (L'obvie et L'obtus 243), Darrieussecq is able to apprehend the raw meaning of her female adolescent body. Moreover, this act of listening is polyphonous. As Kathryn Anderson and Dana Jack underline, “to hear women's perspectives accurately, we have to learn to listen in stereo, receiving both the dominant and muted channels clearly and tuning into them carefully to understand the relationship between them." ${ }^{, 9}$ Indeed, Darrieussecq said that when listening to the tapes, she was fascinated by the noises accompanying her 
adolescent soliloquies such as church bells ringing and the sound of her mother's high heels on the wooden floor. All these peripheral noises were important in the way in which they created living reverberations, serving as an audible reminder of the relationship between her adolescent body and the outer world. Listening to the muted channels also - the pauses, the changes in intonation, the bursts of exasperation, the hues of emotion - Darrieussecq hears the rhythmic, corporeal utterances of the self.

Yet how does one articulate what has been heard? As Darrieussecq has said, the process of listening to the audio diaries did not simply culminate in a transcription of the spoken language of her teenage self; rather, as Paul Bandia underlines, "the expression or representation of oral discourse, whether spoken or written, is always the result of an act of translation." 10 Therefore, it is only via these acts of listening that Darrieussecq is able to textualize the body and translate it into subjective agency. If "when the flesh is made word," as Bernadette Sweeney contends, "it is recorded by a language outside of itself," 11 how do we ensure that the body is not subsumed by pre-established discourses? How can we keep the body's capacity for signifiance intact when it is textualized? For Loffredo, ensuring the body's integrity when translating it into language includes preserving the body's rhythmics in the text. In her translation of Jeanne Hyvrard's Mère la mort (1976), ${ }^{12}$ these textual rhythmics can be understood as "the juncture in which oral, aural and visual features conflate with bodily breathing movements," and she cites punctuation as a tangible sign of the translation of the body into writing, namely, the "presence of the breathing in writing." 13 Yet, I would argue that the way in which Darrieussecq translates the body into language goes beyond gestures of breathing and tonal reverberations. Instead, the vocality contained in the audio diaries allows Darrieussecq, as an intimate listener, to access the physicality of her female adolescent body, via sensorial lived experiences. 


\section{Sensorial translation}

Writing the female body is not something new. In heteropatriarchal discourses the female body is often reduced to the fetishized body-object. Similarly, écriture féminine and Hélène Cixous's call to women, "Écris-toi: il faut que ton corps se fasse entendre,"14 fetishizes the female body, albeit in a different way. A writing that textually celebrates the biologistic images of jouissance and maternal milk reifies the female body, reducing it to an essentialist abstraction. Darrieussecq's endeavor, on the other hand, is different and new, precisely because she is not simply writing the body; rather, she is engaged in translating the body. As a translating writer, Darrieussecq performs what I would call sensorial translation.

When translating the body into language, Darrieussecq pays meticulous attention to the body's impulses, how the body affects and is affected by others and the world it inhabits. Via Solange, Darrieussecq posits the female adolescent body as a body in motion. It is not a thing; instead the body is a situation. As Simone de Beauvoir writes, "si le corps n'est pas une chose, il est une situation: c'est notre prise sur le monde et l'esquisse de nos projets." ${ }^{15}$ In Beauvoirian terms, affirming subjective agency and "becoming" a woman is rooted in a phenomenological epistemology that denotes that gendered subjectivity is acquired through the body's lived experience of acculturation. Solange epitomizes this notion of becoming. As Annabel Kim writes, Darrieussecq's text is about “being an unfixed subjectivity contained within a transitional body" (Kim 9). Darrieussecq explores Solange's body as a situation via her different forms of lived sexual and corporeal experiences over the course of the novel, in her encounters with both herself and others. For Darrieussecq, describing the feelings, the sensations, and the bodily pulsations and movements that accompanied such experiences was crucial, as she explains in the BBC Radio 4 interview: "This feeling of being a very young girl, young body, young thighs and having blood there, I wanted to describe that because it is so banal and nobody talks about it" (Darrieussecq, interview). 
Darrieussecq translates these corporeal sensations experienced by Solange during her first menstruation as follows, focusing on the pruritic effect of the sanitary pad against her skin and the disabling physicality of dysmenorrhea: "Elle marche en serrant les jambes. Une douleur mauve fait des éclats dans les yeux. La serviette hygiénique gratte, se coince. Il est absolument impossible de penser à autre chose" (Clèves 62). Darrieussecq also describes, in detail, Solange's masturbatory practices, concentrating on the body's physical response to Solange's touch, as conveyed here: "Elle frotte, par petits cercles. Un nœud gonfle et se serre, un mécanisme qui se remonte simplement, efficacement à la jonction des os et de la chair, comme si sa charpente osseuse était fait pour porter, au centre, ce bourgeonnement de cœurs charnus" (Clèves 75-76). Darrieussecq also graphically depicts both the corporeal pleasures and displeasures experienced by Solange during sex, for example, when she loses her virginity through anal sex with Arnaud (who prefers this option on the grounds of Solange being on her period): “Tout à coup (c'est très surprenant) ça glisse dedans. Dans le trou qui est là. Voyons les choses en face: dans le trou du caca. Une douleur qui racle” (Clèves 215), and then, in more pleasurable moments when having sex with Monsieur Bihotz: "Toutes les parties de son sexe tubulaire, feuilleté rond, creux et protubérant (une maison de Barbapapa) sont touchées, frottées, pleines et vidées, pressantes et pressées - alors c'est vraiment bon, mieux même que quand elle se masturbe, c'est vraiment super" (Clèves 295). In both of these examples, Darrieussecq sensorially translates these lived experiences into language with a sense of visceral reality; from the searing, piercing anal pain from being unexpectedly sodomized, to the rhythmic and textural descriptions of the pressure, tension, and engorgement in her vagina during sex with Bihotz, Darrieussecq expertly zeros in on the physicality of Solange's sexual body.

\section{(Dis)placing the textual self}


The other way in which Godard sees women's writing as a form of translation is as displacement of the dominant discourse. If phallocentric discourses desubjectify female bodies through fetishist objectification, then Darrieussecq's sensorial translation serves to challenge such discourses, displacing women from patriarchal narratives. One of the ways in which Darrieussecq visualizes this translative process of displacement in the novel is through her inclusion of dictionary definitions, which stand out both typographically and semantically. Interspersed throughout the text are definitions from the Nouveau Larousse universel of the words that Solange looks up, curious to know what they mean, a common occurrence, according to Stevi Jackson, among adolescents when pursuing sexual knowledge. ${ }^{16}$ Yet her forays into "accouplement," "sexe," and "reproduction" (Clèves 39-41) reveal almost nothing of the details of human intimacy, focusing instead on the words' Latin etymology, their medical and zoological definitions, as is illustrated by the reproduction diagram featuring fish, aphids, and algae.

Such sterile, clinical terms stand in sharp contrast to the colorful vernacular Solange hears around her, and her searches for terms such as "pédé" (41), "bite" (42), and "enculer" (Clèves 67) are all in vain. Concerning the latter, Solange turns to Bihotz for explanation. Darrieussecq underlines here how the dynamics of gatekeeping and knowledge are gendered, since Bihotz initially refuses Solange this information on the grounds that it is "un mot très grossier [...] surtout dans la bouche d'une jeune fille" (Clèves 67-68). This privation of knowledge on account of Solange's gender and age is consonant with the way in which sexual scripts are policed according to heteropatriarchal norms whereby any form of sexual agency (herein the desire for sexual knowledge) on the part of teenage girls is scripted as deviant. ${ }^{17}$ Yet Solange is insistent, and eventually Bihotz concedes, using a "petit bilboquet" ([ Clèves ] 69) to explain the term. The French version of this traditional child's toy with its phallic spike is used by Bihotz, who throws its string-attached ball into the air and upon first 
attempt spears it onto the spike, informing Solange that the ball, "Ça, c'est ton cul." (Clèves 69) This gestural act translates the unknown word for Solange, explaining the sexual act, thus underlining Darrieussecq's illustration of how sex and sexuality are knowable only via the lived experience of bodily gestures, not in the sterile pages of a dictionary.

Similarly, Solange looks up female corporeal referents including "vulve" and "vagin," which are defined as follows:

Vulve n.f. [vylv]. Ensemble des parties génitales externes chez la femme et chez les femelles des animaux supérieurs. ENCYCL. La vulve est formée de chaque côté par les grandes lèvres et les petites lèvres, au centre et d'avant en arrière par le clitoris, le méat urinaire et l'orifice du vagin partiellement obturé chez les vierges par l'hymen. || Vagin [vazẽ ] n.m. (lat. vagina, gaine). Canal auquel aboutit le col de l'utérus et qui s'ouvre dans la vulve. ENCLYCL. Le vagin est l'organe femelle de la copulation; il est situé entre la vessie et le rectum. (Clèves 295-96)

In their study of the terms "vagina" and "clitoris" in twenty-eight different medical and English-language dictionaries, Virginia Braun and Celia Kitzinger discover that these referents are often devoid of description of sex and sexuality and tend to be defined in relation to "an implicit penile norm." ${ }^{18}$ Contrasting these two entries with the definition for "penis" in each case, they illustrate how female sexual organs are defined according to binary logic, entrenched in heterosexist assumptions. They highlight how the vagina is implicitly inscribed with passivity through the use of verbs in the dictionary definitions such as "receives" (receives the penis), "serves" (serves as a passageway through which the fetus is delivered), and "allows" (allow the passage of the new-born child); whereas the clitoris is defined as a site of absence, either through word choice such as "partially hidden" to describe 
its location, or via "visual clitoridectomy" in accompanying medical illustrations of female genitalia (Braun and Kitzinger 224-26).

Indeed, the definitions that Solange encounters in the Nouveau Larousse universel echo such findings, with the vaginal orifice being described according to heterosexual dictum. The explanation that the vaginal opening is partially sealed by the hymen in the case of virgins codifies the female body according to a heteropatriarchal construction of sexuality. Yet Darrieussecq's depictions of Solange's own corporeal lived experiences work to undermine such definitions. Solange's own hymen is not broken when she loses her virginity to Arnaud but rather, later, when she has intercourse with Bihotz. Even the architecture of the text has been constructed by Darrieussecq in such a way that these dictionary definitions are textually undone by the surrounding narrative, as either before or after each term there appears a description of how Solange's own experiences juxtapose the static definitions offered by the Larousse.

The dictionary entries Darrieussecq includes serve as fitting examples of the seemingly neutral and unified discourse of the universal, yet her indication of the possibility for other discourses to coexist dislodges the monolithism of the dominant discourse. Thus, via these acts of displacement, Darrieussecq's writing is a form of translation, as Godard contends. Translation displaces dominant discourses by robbing them of some of their putative authority, which, as Maeve Cook signals, can have an emancipatory dimension since it "may offer the possibility of disrupting the established discourse that controls and defines the parameters of the universal." ${ }^{19}$ Darrieussecq's translational praxis here, then, can be understood in terms of what Homi Bhabha calls "cultural translation," ${ }^{20}$ namely, a pluralizing of the universal, which, as Judith Butler argues, allows those previously excluded from its discourse to enter into dialogue with it, potentially reshaping and re-envisioning its parameters. ${ }^{21}$ Carving out textual space for these forms of sexuality, corporeally experienced 
by Solange as an adolescent female subject, illustrates how Darrieussecq manages to translate female sexuality out from obscurity.

\section{Translation as embodied reading}

Yet what happens to Solange and to her adolescent sexual body, so carefully translated into subjective agency by Darrieussecq, when it is textualized in a different cultural and linguistic context by another body, namely, another translator? In her English translation, All the Way, does Hueston engage in similar processes of sensorial translation? Does her translation praxis also involve displacing dominant discourse, and if so, how are such manifestations of heteropatriarchal order productively undone in a different socio-linguistic textual space? According to Loffredo, bodies surface in translation, in amplified and magnified ways, and in the same way in which Darrieussecq translates the female adolescent body from its state of signifiance into language, so too must Hueston engage with practices of translation beyond the purely linguistic. Instead "she is involved with [the body's] rhythmics, in other words, with the idiosyncratic physical configuration of a subjectivity inscribed in text" (Loffredo, “The Diseased Body of Language” 490). In order to apprehend Solange's subjectivity, Hueston must enter a dialogical translation space that implicates her own translating body. As Douglas Robinson suggests, "when we read novels and poems, we respond physically to them, fleshing them out with the sense-memories (sights, sounds, smells, etc.) and emotionmemories (amusement, romance, suspense, terror, etc.) of our own experience." ${ }^{22}$ As an intimate reader of a text, first and foremost, Hueston's translation approach to this organic writing is informed by her idiosomatic responses to the text.

As José Santaemilia contends, the translation of sex and sexuality "is fully indicative of the translator's attitude towards existing conceptualizations of gender/sexual identities, human sexual behaviors and society's moral norms." 23 An interesting example of Hueston's 
somatic response to the text is evident in how the female adolescent body is textualized differently in English. Part of Darrieussecq's project in writing an organic book involves explicitly naming the female body, specifically focalizing genitalia in Solange's sexual encounters and practices. Darrieussecq often uses the somewhat neutral French term "le sexe": “il l'embrasse et s'enfonce plus loin, main collée à son sexe ventousant et mouillé” (Clèves 106); "Son sexe la démange, moite et grumeleux comme une poire blette. Elle baise trop" (Clèves 304), and the more informal, "la chatte": "Laetitia avait une espèce de bite en plastique qu'elle a voulu lui mettre dans le derrière, enfin dans la chatte" (Clèves 261). Interestingly, in all of these examples, Hueston opts for the more expletive word "cunt": "he kisses her and pushes his finger in further; his hand stuck to her sucking wet cunt" (All the Way 74); "Her cunt is driving her crazy, it's so itchy, sticky and swollen like an overripe pear. Too much fucking" (All the Way 218), and "Laetitia had a sort of plastic dick that she wanted to put in Solange's bottom, well, in her cunt" (Đarrieussecq, All the Way 186). In contemplating how to translate the term in the line "I wonder about the smell of cunt" from Gail Scott's Heroine (1987), ${ }^{24}$ feminist translator Susanne de Lotbinière-Harwood reflects on the fact that this word (as is the case with many words related to women's bodies, she adds) "est couramment employé comme juron en anglais et en français" 25 and consequently employs the French cognate "con" in order to mirror the source text's transgressive value. Yet Darrieussecq does not employ the word "con," and Hueston could have had recourse to cognates such as "sex" (albeit a more infrequent term to designate genitalia in English) and "pussy," implying that her different lexical choice was linked instead to a somatic reflex. In each of the three examples cited above, Solange's body is described in a state of sexual vulnerability: in the first, she is being fingered by a fireman at a disco celebrating his last night as a bachelor; then, in the second, she is suffering from vaginal thrush due to the frequency of sexual intercourse with her childminder, Bihotz; and thirdly, as the potential 
sexual conquest of her lesbian classmate. Hueston's use of the term "cunt," then, can be interpreted as a defense mechanism against this threat of sexual objectification, instead Hueston asserts Solange's sexual agency by brazenly staking her claim over her sexual body via these provocative textual transgressions in English.

Furthermore, subtle changes in vocabulary linked with sensation hint at the way in which the text undergoes transformation when it is experienced differently through the body of the translator, with Hueston's own corporeal responses left as indelible textual traces. For instance, the sense of sexual arousal Solange experiences as she becomes aware of the role she must play ([ as ] i.e. desirable and experienced) when performing fellatio on Arnaud is described as "Un trouble délicieux" (Clèves 160), which, in English, becomes, "An exquisite shuddering" (All the Way 113). Similarly, when she has sex with Bihotz for the first time, Solange is described as follows: "Elle souffle et respire. Elle monte et descend, bien campée sur ses cuisses, c'est comme un cheval, mais quand même pas tout à fait" (Clèves 293), whereas, in Hueston's English translation, “She’s sighing and panting. She's riding up and down, sitting squarely on his thighs, like a horse but still not quite like that" (All the Way 209). These different expressions of physicality in English, "shuddering," "sighing," and "panting," which all depart from the French in their recognizably more palpable corporeal gestures, are examples of Hueston's kinesthetic translation practice. As Clive Scott states, "translation is about registering the text in my body, and conversely, inscribing in text my bodily responses." ${ }^{26}$ These lived sensorial experiences of the female adolscent body, which Darrieussecq had to bring into language via her own processes of translation, equally are not simply pre-existing in English for Hueston to access readily. Instead, these sensorial bodily gestures can be apprehended by Hueston only when she enters physically into a dialogical space with them. As an embodied, performative act, then, Hueston's translation choices for these terms are indicative of her own corporeal inflection on the text. 


\section{Displacing the dominant discourse differently}

Just as Darrieussecq's translational praxis of writing Solange into subjective being involves a displacement of the dominant discourse, so too is Hueston involved in these processes of disarticulation and rearticulating. Yet, as discourse is constituted via language, Hueston has to negotiate its different linguistic manifestations in English.

Darrieussecq's inclusion of the dictionary entries is an integral part of the narrative, and the definitions are intrinsically (yet, often diametrically) tied to Solange's lived experiences, but they are inseparable from their French linguistic specificity. Even though Hueston does not actually domesticate the text -- for example, Solange is still a French girl, living in the French fictional seaside town of Clèves, and she is still looking up words in the Nouveau Larousse universel -- it would be prohibitive and counterproductive for Hueston simply to 'borrow' the French definitions verbatim. ${ }^{27}$ So, when Solange searches for the word "bite" and is frustrated to find "Il n'y a rien à bite sauf avec deux t, 'bitte n.f. (du scandin. biti), pièce de bois ou de métal fixée sur le point d'un navire et sur laquelle sont tournées les amarres" (Clèves 42), Hueston must creatively intervene in the target text in order to create a similar resonance for her reader. In response, she comes up with the following: "There's nothing for dick except 'Spotted dick n. a British steamed suet pudding containing dried fruit (usually currents) commonly served with custard" (All the Way 26-27). Her translation is effective on multiple levels: first, like "bitte," "spotted dick" keeps formal morphological consonance with the word Solange was originally interested in, and second, similar to the definition given for "bitte," namely a wooden or metal mooring post, the reference to the British suppertime staple is equally unerotic.

Another way in which Darrieussecq displaces the dominant discourse is via the language employed by Solange and her friends, which playfully undoes sexual discourses 
through their subversive adolescent wordplay. For example, when Solange hesitates about what to tell her two friends, Rose and Concepción, about her encounter with the fireman, she says, “Elle hésite à dire qu'elle a couché. Ce serait un trop gros mensonge. Certes ce n’est pas écrit sur le front. Mais il lui semble que ça se voit, chez Rose. Depucelée. Comme une chienne qu'on aurait traitée pour ses puces" (Clèves 116). Solange's unfamiliarity with this lived experience is illustrated in her textual deconstructing of the term, subverting its sexual definition by diverting it to a mundane act. The same play on words does not transfer across to English, and instead, Hueston translates as follows: "She's not sure about saying that she slept with him. That would be too much of a lie. Okay, it's not written on your forehead. But she thinks it's obvious - with Rose it is. Deflowered. Like a bush that has been stripped of its flowers" (All the Way 81). Again, Hueston imbues the target text with the same resonances as its source. Ludically deconstructing this common euphemism for the loss of virginity, Hueston, in echoing Darrieussecq, underlines the comic inadequacy of language to represent women's lived sexual experiences. What is more, Hueston simultaneously creates a fortuitously opportune linguistic link to the character in question, Rose, to boot.

Finally, Darrieussecq also uses language associated with childhood such as songs, nursery rhymes, and fairy tales to subvert dominant sexual discourses. For instance, when Solange has sex with Bihotz for the first time, her actions - of straddling him and of rocking naked back and forth on his lap before eventual vaginal penetration - are described in terms of a French nursery rhyme: "les tissus et les chairs s'écartent, ça résiste un tout petit peu, elle se balance et rebalance, bateau batelier ton bateau va chavirer - et quelque chose - dong se met en place avec la force d'un ressort" (Clèves 293). Darrieussecq uses the nursery rhyme, in part, to remind the reader of the way in which the relationship with Bihotz, who was once (and to some extent remains) Solange's childminder, has been perverted. But the replacement of sexual imagery with childlike imagery also reinforces the way in which female adolescent 
sexuality has been excluded from dominant sexual narratives. Hueston finds an apparent literary equivalent in English and translates the scenes as follows: "clothing and flesh part, it's a bit hard at first, she rocks forward and repositions herself, See Saw Marjorie Daw - and something - boing - pops in place like a spring" (All the Way 209). Although this would appear as a correlating translation strategy, the line "See Saw Marjorie Daw" in isolation, in English, from the rest of the nursery rhyme, imbues the scene with an additional meaning. In the Scots language, the word 'daw' refers to a slut, as in the Scottish proverb, "He that marries a daw, eats meikle dirt." ${ }^{28}$ In the Oxford Dictionary of Nursery Rhymes, the following version of the song is given:

See-saw, Margery Daw,

Sold her bed and lay on the straw;

Sold her bed and lay upon hay

And pisky came and carried her away.

For wasn't she a dirty slut

To sell her bed and lie in the dirt? ${ }^{29}$

In this light, Hueston's translation casts Solange in the role of "Marjorie Daw," simultaneously imposing an implicit moral judgment upon her sexual behavior. The role reversal is an interesting one when compared with Darrieussecq's French text, since the nursery rhyme is associated with Solange's childish innocence and consequently Bihotz's abuse of power. Yet viewing Solange through the lens of the English translation allows the possibility to see Solange as the one who is asserting sexual agency. As such, this example illustrates how bodies, brokered via translational practices, do not necessarily inhabit the same spaces in different cultural and linguistic contexts. 


\section{Conclusion}

"Translation," Godard writes, "in its figurative meanings of transcoding and transformation, is a topos in feminist discourse used by women writers to evoke the difficulty of breaking out of silence in order to communicate new insights into women's experiences and their relation to language" (Godard 45). As this study has illustrated, both Darrieussecq and Hueston are engaged in translation; both are engaged in practices of transcoding and transformation in order to bring adolescent female sexuality out from obscurity, carving out and transforming textual spaces to make room for Solange's lived realities, endowing her not only with subjectivity but, more specifically, with tangible authenticity. ${ }^{30}$ For both Darrieussecq and Hueston, translation is a situated, embodied praxis. It is only via the bodily act of listening that Darrieussecq can apprehend her own, younger body and transcode its signifiance, accessible only via the corporeal reverberations of this past body's vocality. Similarly, it is only via the bodily act of reading that Hueston is able to access this newly textualized body, somatically transcoding it into English in rhythm with her own corporeal inflections. Equally, their translation praxis, in both similar and divergent ways, involves displacing dominant discourses. The textually pervasive heteropatriarchal discourses that threaten to reinsert Solange into their existing narratives do not look dissimilar in French and in English, and the textual countermeasures that Darrieussecq and Hueston employ to resist them are as subversive and playful as one another. Translation is frequently conceptualized as a form of rewriting, ${ }^{31}$ often as a way to displace it from subservient discourses of reproduction. Yet, I would argue that such a definition is in and of itself counterproductively limiting. Instead of defining translation in terms of its relational quality to writing, swapping the signifiers around and namely understanding writing as translation, allows us better to apprehend its full transformative potential. Translation as a source of both mutability and plurality can open up 
new vistas for understanding and for being in the world. That is why it is only via translation that both Darrieussecq and Hueston can write Solange into subjective agency.

Newcastle University

\section{Notes}

${ }^{1}$ Marie Darrieussecq, Clèves (Paris: P.O.L., 2011); English trans., All the Way, Penny Hueston, trans. (Melbourne: The Text Publishing Company, 2013).

${ }^{2}$ Marie Darrieussecq, “The Grand Budapest Hotel; Marie Darrieussecq; Alan Ayckbourn.” Interview by Samira Ahmed. Front Row, BBC Radio 4, March 3, 2014. Audio. https://www.bbc.co.uk/programmes/b03wpdy8

${ }^{3}$ As Annabel Kim points out, Clèves was at the forefront of French readers' minds at the time of publication, given the recent dismissive remarks made about Madame de Lafayette's $L a$ Princesse de Clèves (1678) by the then French President, Nicolas Sarkozy. See Annabel L. Kim, “Marie Darrieussecq's Clèves: A Wittigian Rewriting of Adolescence," Studies in $20^{\text {th }}$ and $21^{\text {st }}$ Century Literature, 40:1 (2016): 1 and 17-18 (note 1).

${ }^{4}$ Barbara Godard, “Theorizing Feminist Discourse/Translation,” Tessera, 6 (1989): 45.

${ }^{5}$ Susan Husserl-Kapit and Marguerite Duras, “An Interview with Marguerite Duras,” Signs, 1:2 (1975): 425.

${ }^{6}$ Roland Barthes, Le grain de la voix: Entretiens 1962-1980 (Paris: Seuil, 1981), 58.

${ }^{7}$ Roland Barthes, L'obvie et l'obtus (Paris: Seuil, 1982), 241.

${ }^{8}$ Eugenia Loffredo, "The Translator's Voyage into Madness: An Experimental Translation of Jeanne Hyvrard's Mère la mort”' (PhD diss., University of East Anglia, 2002), 35. 
${ }^{9}$ Kathryn Anderson and Dana C. Jack, "Learning to Listen: Interview Techniques and Analyses," Women's Words: The Feminist Practice of Oral History, Sherna Berger Gluck and Daphne Patai, eds. (London: Routledge, 1991), 11.

${ }^{10}$ Paul Bandia, “Orality and Translation," Handbook of Translation Studies, vol. 2, Yves Gambier and Luc van Doorslaer, eds. (Amsterdam: John Benjamins Publishing, 2011), 108.

${ }^{11}$ Bernadette Sweeney, "Wordmadeflesh: Writing the Body in Irish Theatre," Modern Drama, 47:4 (2004): 686.

12 Jeanne Hyvrard, Mère la mort (Paris: Les Éditions de Minuit, 1976).

${ }^{13}$ Eugenia Loffredo, "The Diseased Body of Language: Translating the Female Body in Jeanne Hyvrard's Mère la mort," Género, lenguaje y traducción, José Santaemilia, ed. (Valencia: Universidad de Valencia), 489.

${ }^{14}$ Hélène Cixous, “Le rire de la Méduse,” L'arc, 61 (1975): 43.

${ }^{15}$ Simone de Beauvoir, Le Deuxième Sexe, tome 1 (1949) (Paris: Gallimard, 1976), 75.

${ }^{16}$ Stevi Jackson, Heterosexuality in Question (London: Sage, 1999), 70.

${ }^{17}$ Michael W. Wiederman, "The Gendered Nature of Sexual Scripts," The Family Journal, 13:4 (2005): 496-502.

${ }^{18}$ Virginia Braun and Celia Kitzinger, “Telling It Straight? Dictionary Definitions of Women's Genitals," Journal of Sociolinguistics, 5:2 (2001): 223.

${ }^{19}$ Maeve Cook, Re-Presenting the Good Society (Cambridge, MA: MIT Press, 2006), 82.

${ }^{20}$ Homi Bhabha, The Location of Culture (London: Routledge, 1994).

${ }^{21}$ Judith Butler, Undoing Gender (New York: Routledge, 2004), 38.

${ }^{22}$ Douglas Robinson, The Translator's Turn (Baltimore: Johns Hopkins U P, 1991), 5.

${ }^{23}$ José Santaemilia, “Translating Sex(uality) from English into Spanish and Vice-versa: A Cultural and Ideological Challenge," Atlantis, Journal of the Spanish Association of AngloAmerican Studies, 37:1 (2005): 139. 
${ }^{24}$ Gail Scott, Heroine (Toronto: Coach House Press, 1987), 150.

${ }^{25}$ Susanne de Lotbinière-Harwood, Re-Belle et Infidèle: La traduction comme pratique de réécriture au féminin / The Body Bilingual: Translation as a Rewriting in the Feminine (Montréal/Toronto: Les Éditions du Remue-Ménage / The Women’s Press, 1991), 64. ${ }^{26}$ Clive Scott, Literary Translation and the Rediscovery of Reading (Cambridge: Cambridge U P, 2012), 12.

27 "Borrow" here in the sense of one of the seven translation procedures proposed by JeanPaul Vinay and Jean Darbelnet, whereby a source text word or phrase is retained in the target text, either due to the absence of a lexical equivalent or for stylistic purposes. Jean-Paul Vinay and Jean Darbelnet, Stylistique comparée du français et de l'anglais (Paris: Didier, 1973).

${ }^{28}$ John Jamieson, An Etymological Dictionary of the Scottish Language: Volume 1 (Edinburgh: Creech, Constable, and Blackwood, 1808).

${ }^{29}$ Iona Opie and Peter Opie, The Oxford Dictionary of Nursery Rhymes (1951), 2nd ed. (Oxford U P, 1997), 297-98.

${ }^{30}$ I am using "authenticity" here in the Beauvoirian, existentialist sense, seeing Solange as a subject, capable of transcendence. Simone de Beauvoir, Le Deuxième Sexe, tome II (1949) (Paris: Gallimard, 1976), 133.

${ }^{31}$ André Lefevere, Translation, Rewriting and the Manipulation of Literary Fame (London: Routledge, 1992). 